\title{
Optimasi Pretreatment melalui Metode Hydrothermal Pressure dan Pelarut Alkali pada Produksi Bioetanol dari Lemna minor
}

\author{
Abdur Rahman Arif ${ }^{\text {a,c*) }}$, Andi Evi Erviani ${ }^{\text {b) }}$, Hasnah Natsir ${ }^{a, c)}$, Ilham Haidir ${ }^{c)}$, Maudy \\ Audina Affandy ${ }^{\mathrm{c}}$ \\ a) Department of Chemistry, Faculty of Mathematics and Natural Sciences, Hasanuddin University, \\ Tamalanrea, Makassar, South Sulawesi, Indonesia, 90245. \\ ${ }^{b)}$ Department of Biology, Faculty of Mathematics and Natural Sciences, Hasanuddin University, \\ Tamalanrea, Makassar, South Sulawesi, Indonesia, 90245. \\ ${ }^{c)}$ Biochemistry Laboratory, Department of Chemistry, Faculty of Mathematics and Natural Sciences, \\ Hasanuddin University, Tamalanrea, Makassar, South Sulawesi, Indonesia, 90245. \\ * Corresponding author
}

E-mail: arrahman.arif@unhas.ac.idatau_ar_rahman_arif08@yahoo.com

DOI: 10.20961/alchemy.14.1.15986.95-106

Received 15 November 2017, Accepted 18 December 2017, Published 1 March 2018

\begin{abstract}
ABSTRAK
Produk bioetanol dengan bahan dasar biomassa lignoselulosa perlahan banyak dikembangkan sebagai sumber energi alternatif. Tantangan utama dalam produksi lignoselulosa etanol berada pada tahap pretreatment. Pretreatment merupakan tahap yang memegang peranan penting dalam mendegradasi lignoselulosa menjadi selulosa. Pada penelitian ini digunakan Lemna minor yang merupakan gulma perairan dengan kombinasi dua tahap pretreatmen untuk melihat efektivitas degradasi lignoselulosa dalam sampel. Tahap pertama dengan metode hydrothermal pressure pada suhu pemanasan uap $121{ }^{\circ} \mathrm{C}$ dan tekanan $15-20$ psi dengan variasi waktu proses selama 5, 15, 30, 45, dan 60 menit. Tahap kedua pretreatment dengan metode kimiawi menggunakan $\mathrm{NaOH}$ dengan variasi konsentrasi 0,$5 ; 1 ; 1,5 ; 2$; dan 2,5 M. Hasil penelitian menunjukkan 60 menit merupakan waktu optimum dari metode hydrothermal pressure pada sampel L. minor dengan kadar lignin 11,32\%, kadar selulosa 17,39\%, kadar hemiselulosa 16,73\% dan kadar gula total 0,82\%. Untuk tahapan pretreatment dengan pelarut alkali $(\mathrm{NaOH})$ kandungan kadar lignin L. minor setelah pretreatment dengan $\mathrm{NaOH}$ 2,0 M sebesar 5,36\%, kadar. Kandungan kadar selulosa, hemiselulosa dan gula total optimum diperoleh pada konsentrasi 2,5 M dengan nilai kadar 31,03\%; 5,57\% dan 1,74\%. Efektivitas penurunan kadar lignin pada pretreatment hydrothermal pressure sebesar 37,04\% sedangkan pretreatment dengan $\mathrm{NaOH}$ sebesar 70,18\%. Kombinasi proses pretreatment memberikan hasil yang cukup baik terhadap proses degradasi lignin yang terkandung dalam sampel Lemna minor sehingga sangat efektif digunakan dalam proses pembuatan bioetanol dengan bahan dasar biomassa.
\end{abstract}

Kata kunci: hydrothermal pressure, Lemna minor, lignoselulosa, $\mathrm{NaOH}$, pretreatment

\begin{abstract}
Optimization Pretreatment through Hidrothermal Preassure and Alkaline Solvent Methods in Bioethanol Production from Lemna minor. Bioethanol products with lignocellulosic biomass feedstock have been developed as an alternative energy source. The main challenge in the production of lignocellulosic ethanol is on the pretreatment stage. Pretreatment is a stage that plays an important role in degrading lignocellulose into cellulose. In this study, we used a Lemna minor which is a water weed with a combination
\end{abstract}


of two stages of pretreatmentt to see the effectiveness of lignocellulosic degradation in the sample. The first stage is hydrothermal pressure method of steam heating temperature $121{ }^{\circ} \mathrm{C}$ and pressure $15-20$ psi with variation of processing time for $5,15,30,45$, and 60 minutes. The second stage of pretreatment with chemical methods using $\mathrm{NaOH}$ with a concentration variation of $0.5 ; 1 ; 1.5 ; 2$ and $2.5 \mathrm{M}$. The results showed that 60 minutes was the optimum time of the hydrothermal pressure method in the L. minor sample with the lignin content of $11.32 \%$, the cellulose $17.39 \%$, the hemicellulose $16.73 \%$ and the total sugar $0.82 \%$. For the pretreatment stage with alkaline solvent $(\mathrm{NaOH})$ the content of $L$. minor lignin after pretreatment with $2.0 \mathrm{M}$ $\mathrm{NaOH}$ was $5.36 \%$. The content of cellulose, hemicellulose and total sugars was obtained at a concentration of $2.5 \mathrm{M}$ with a grade value of $31.03 \%, 5.57 \%$, and $1.74 \%$. The effectiveness of lignin decrease in pretreatment hydrothermal pressure was $37.04 \%$ while pretreatmentt with $\mathrm{NaOH}$ was $70.18 \%$. The combination of pretreatment process gives a good result to the lignin degradation process contained in the L. minor sample in order that it is very effective in the process of making bioethanol with biomass feedstock.

Keywords: hydrothermal pressure, Lemna minor, lignocellulose, $\mathrm{NaOH}$, pretreatment

\section{PENDAHULUAN}

Krisis energi di dunia telah mendorong pencarian bahan bakar alternatif sebagai pengganti bahan bakar yang berasal dari minyak bumi. Sifat dari bahan bakar fosil tidak dapat diperbaharui karena jumlahnya yang terbatas, selain itu pemakaian utama bahan bakar fosil banyak dikonsumsi oleh sektor industri dan transportasi menjadi faktor utama meningkatnya emisi gas rumah kaca, dan polusi (Atabani et al. 2012). Hal tersebut menjadi dasar utama pencarian bahan bakar baru. Bahan bakar alternatif yang layak dikembangkan adalah bahan bakar yang bersifat renewable atau terbarukan, ramah lingkungan, dan efisien. Beberapa sumber energi terbarukan yang saat ini digunakan sebagai energi alternatif antara lain berasal dari angin, panas bumi, sinar ultraviolet, air dan biomassa. Hal ini dapat dilakukan dengan mengembangkan energi yang berasal dari bahan biomassa. Secara kuantitas bahan baku biomassa begitu melimpah dan mudah untuk didapatkan. Salah satu biomassa yang potensial untuk dikembangkan adalah biomassa Lemna minor $(L$. minor).

L. minor merupakan gulma perairan yang hidup dipermukaan air dengan periode serta pola pertumbuhan yang panjang dan sangat cepat (Xu et al., 2011). L. minor banyak tumbuh di pinggir sawah, tambak dan selokan dan terkadang menutupi keseluruhan permukan air. Secara komposisi, L. minor mengandung karbohidrat sebesar 40-50\%, lipid 3-7\% dan abu 24\% (Gwaze and Mwale, 2015; Zhao et al., 2014). Kandungan karbohidrat yang cukup signifikan pada L. minor sangat potensial untuk dijadikan sebagai sumber bioetanol. Salah satu tantangan utama dalam produksi bioetanol berbasis biomassa adalah sulitnya memecah holoselulosa menjadi monomer gula yang bisa difermentasi menjadi etanol. Pengembangan teknologi pretreatment merupakan salah satu solusi untuk memecahkan permasalahan ini. Keberhasilan pretreatment biomassa lignoselulosa akan 
membuka jalan dalam mengembangkan teknologi produksi bioetanol. Selama ini metode pretreatment telah banyak dikembangkan dalam proses pemecahan lignoselulosa pada biomassa. Beberapa penelitian tentang metode pretreatment lignoselulosa antara lain metode pretreatment jerami padi dengan amonia (Ko et al., 2009) dan larutan ionik (Li et al., 2010), pretreatment dengan metode steam explosion (Ballesteros et al., 2006), pretreatment menggunakan supercritical $\mathrm{CO}_{2}(\mathrm{Gu}$ et al., 2013), dan pretreatment secara biologi menggunakan mikroba baik bakteri maupun jamur (Parisutham et al., 2014; Wan and $\mathrm{Li}, 2012$ ). Pada penelitian ini dilakukan kombinasi pretreatment bertingkat secara fisika-kimia dengan metode hydrothermal pressure dan pelarut alkali natrium hidroksida sebagai agen pendegradasi lignoselulosa pada L. minor. Perpaduan kedua metode ini diharapkan efektif dalam meningkatkan produksi bioetanol berbasis biomassa.

\section{METODE PENELITIAN}

Bahan yang digunakan dalam penelitian ini antara lain tanaman air L. minor yang dikumpulkan dari kolam yang airnya tergenang di Kabupaten Sinjai, Natrium hidroksida $(\mathrm{NaOH})$ merck KGaA 99\% CAS-No: 1310-73-2, aluminium foil klin pak, cling wrap klin pak, aquades, kertas saring whatman no. 42. Alat yang digunakan dalam penelitian ini antara lain grinder retschmuhle type DR. 80 b/2q.q, shieve shaker restch AS 200 basic Germany, cawan petri pyrex, oven genlab Ltd $275^{\circ} \mathrm{C}$, furnance nabertherm Tmax 1100$1200{ }^{\circ} \mathrm{C}$, neraca analitik ohauss adventure pro tipe AV264C, multiple heating magnetic stirrer AM4 Velp scientifia, tabung reaksi pyrex, autoklaf napco tipe 8000DES, penyaring buchner pyrex.

\section{Persiapan bahan baku}

L. minor yang telah dikumpulkan diangin-anginkan hingga kering tanpa sinar matahari langsung. L. minor yang telah kering digiling menggunakan grinder unuk memperkecil ukuran partikelnya. Serbuk hasil penggilingan selanjutnya diayak dengan ayakan 60 mesh.

\section{Analisis awal lignin, selulosa dan hemiselulosa}

Sampel yang telah diayak selanjutnya dilakukan analisis awal terhadap kadar selulosa, hemiselulosa dan lignin dengan metode Chesson (Datta, 1981).

\section{Pretreatment bertingkat}

\section{Hydrothermal pressure pretreatment}

Proses pretreatment awal dilakukan secara fisika dengan metode hydrothermal pressure. Masing-masing serbuk L. minor sebanyak $10 \mathrm{~g}$ dimasukan ke dalam 5 buah 
cawan petri. Setelah itu sampel dimasukkan ke dalam autoklaf, kemudian dipanaskan dengan hydrothermal pressure pada suhu $121{ }^{\circ} \mathrm{C}$, tekanan $15-21$ psi dengan variasi waktu perlakuan yaitu 5; 15; 30; 45; dan 60 menit. Sampel kemudian didinginkan lalu dilakukan analisis kandungan kadar lignin, selulosa, hemiselulosa dengan metode Chesson dan kadar gula total dengan metode Luff Schoorl. Waktu optimum degradasi lignoselulosa digunakan sebagai acuan untuk melakukan proses pretreatment secara kimiawi dengan pelarut alkali $(\mathrm{NaOH})$.

\section{Metode kimiawi dengan pelarut alkali $(\mathrm{NaOH})$}

Sampel hasil pemanasan hydrothermal pressure sebanyak $10 \mathrm{~g}$ kemudian dimasukkan ke dalam cawan petri. Selanjutnya dipanaskan dengan hydrothermal pressure pada waktu optimum, dilanjutkan dengan pretreatment menggunakan larutan $\mathrm{NaOH}$ dengan variasi konsentrasi 0,$5 ; 1 ; 1,5 ; 2 ; 2,5$; dan $3 \%$. Dilakukan dengan cara perendaman dan pengadukan selama 1 jam. Residu dan filtrat dipisahkan kemudian dikeringkan di oven pada suhu $105^{\circ} \mathrm{C}$ sampai berat konstan (Selig et al., 2009). Setelah itu dilanjutkan dengan proses analisis lignin, hemiselulosa, selulosa dengan metode Chesson dan kadar gula total dengan metode Luff Schoorl.

Analisis kadar lignin, hemiselulosa dan selulosa dengan metode Chesson (Datta, 1981)

Sebanyak $1 \mathrm{~g}$ (a) sampel kering ditambahkan $150 \mathrm{~mL}$ akuades, direfluks pada suhu $100{ }^{\circ} \mathrm{C}$ dengan water bath selama 1 jam. Hasilnya disaring, residu dicuci dengan air panas (300 mL). Residu kemudian dikeringkan dengan oven sampai konstan kemudian ditimbang (b). Residu ditambahkan denan $150 \mathrm{~mL} \mathrm{H}_{2} \mathrm{SO}_{4} 1 \mathrm{~N}$ kemudian direfluks dengan water bath selama 1 jam pada suhu $100{ }^{\circ} \mathrm{C}$. Hasilnya disaring dan dicuci dengan akuades sampai netral (300 mL) lalu dikeringkan (c). Residu kering ditambahkan $10 \mathrm{~mL} \mathrm{H}_{2} \mathrm{SO}_{4} 72 \%$ dan direndam pada suhu kamar selama 4 jam. Ditambahkan $150 \mathrm{~mL} \mathrm{H}_{2} \mathrm{SO}_{4} 1 \mathrm{~N}$ dan direfluks pada water bath selama 1 jam pada pendingin balik. Residu disaring dan dicuci dengan akuades sampai netral (400 mL) kemudian dipanaskan dalam oven pada suhu $105{ }^{\circ} \mathrm{C}$ dan hasilnya ditimbang sampai bobot tetap (d), selanjutnya residu diabukan dan ditimbang (e). Perhitungan kadar selulosa dan kadar lignin didasarkan pada persamaan (1), (2) dan (3):

$$
\begin{array}{ll}
\text { Kadar selulosa } & : \frac{c-d}{a} \times 100 \% \\
\text { Kadar lignin } & : \frac{d-e}{a} \times 100 \% \\
\text { Kadar hemiselulosa } & : \frac{b-c}{a} \times 100 \%
\end{array}
$$

Dimana : $\quad \mathrm{a}=$ berat sampel $(\mathrm{g})$

$\mathrm{b}=$ berat residu penimbangan kedua $(\mathrm{g})$ 


$$
\begin{aligned}
& \mathrm{c}=\text { berat residu pada penimbangan ketiga }(\mathrm{g}) \\
& \mathrm{d}=\text { berat residu pada penimbangan keempat }(\mathrm{g}) \\
& \mathrm{e}=\text { berat abu }(\mathrm{g})
\end{aligned}
$$

\section{Analisis kadar gula total dengan metode Luff Schoorl (Marrubini et al., 2017)}

Penentuan kadar gula total diawali dengan preparasi sampel terlebih dahulu. Ditimbang sampel halus sebanyak 2,5 g ke dalam labu ukur $250 \mathrm{~mL}$, ditambahkan akuades sebanyak $50 \mathrm{~mL}, 40 \mathrm{~mL} \mathrm{~Pb}$-asetat 5\%, dikocok, ditambah $5 \mathrm{~mL} \mathrm{Na-fosfat} \mathrm{5 \% ,} \mathrm{kocok} \mathrm{kuat}$ selama 1 menit, tambahkan akuades sampai batas labu ukur. Filtrat yang diperoleh, diuapkan dengan hotplate sampai didapat $1 / 2$ volume awal, didinginkan, dipindahkan ke labu ukur $100 \mathrm{~mL}$, dan ditambah akuades sampai tanda batas sehingga diperoleh larutan A. Sebanyak $50 \mathrm{~mL}$ larutan A, ditambah 5 tetes indikator metil orange dan $20 \mathrm{~mL} \mathrm{HCl} 4 \mathrm{~N}$, larutan dipanaskan selama 30 menit, dinginkan sampai suhu menjadi $20{ }^{\circ} \mathrm{C}$. Kemudian dinetralkan dengan $\mathrm{NaOH} 4 \mathrm{~N}$, ditepatkan dengan akuades sampai tanda batas sehingga diperoleh larutan B. Setelah larutan sampel telah siap, dilakukan prosedur penetapan gula total dengan memasukkan $25 \mathrm{~mL}$ sampel ke dalam labu destilasi dan direfluks selama 15 menit, didinginkan, ditambah $10 \mathrm{~mL} \mathrm{KCl} 30 \%$ dan $25 \mathrm{~mL} \mathrm{H}_{2} \mathrm{SO}_{4} 6 \mathrm{~N}$, kemudian dititrasi dengan larutan tiosulfat $0,1 \mathrm{~N}$ hingga berwarna kuning jerami. Hasil titrasi ditambahkan dengan $2 \mathrm{~mL}$ amilum $1 \%$ dan dititrasi dengan natrium tiosulfat $0,1 \mathrm{~N}$ sampai berwarna putih susu. Titrasi juga dilakukan terhadap blanko. Penentuan kadar gula reduksi ditentukan dengan perhitungan selisih dari titrasi blanko dengan titrasi sampel yang kemudian hasilnya dikorelasikan dengan tabel Luff Schoorl. Kadar gula reduksi dihitung menggunakan persamaan (4), (5), dan (6):

$$
\begin{aligned}
& a=\frac{(\text { Vblanko }- \text { Vnatio })(\text { rata }- \text { rata standarisasi })}{\text { Normalitas standar }} \\
& b=\frac{\mathrm{Xa}+(\mathrm{a}-\mathrm{Bb})(\mathrm{Xb}-\mathrm{Xa})}{\mathrm{Ba}-\mathrm{Bb}} \times 0,09531
\end{aligned}
$$

Kadar gula total dihitung dengan persamaan:

$$
\text { Kadar gula total }=\frac{b}{\text { Wsampel }} \times \text { Fp } \times 100 \%
$$

\section{PEMBAHASAN}

\section{Analisa awal lignin, selulosa dan hemiselulosa}

Proses awal analisis komposisi L. minor dilakukan untuk melihat perbandingan kadar lignin, selulosa dan hemiselulosa dengan kadar sampel setelah dilakukan proses pretreatment. Metode analisis lignin, selulosa dan hemiselulosa yang diadopsi adalah metode chesson (Datta, 1981). Hasil analisis kadar lignin, selulosa dan hemiselulosa dari 
10,245 g sampel L. minor menunjukkan komposisi kadar yang berbeda. Data komposisi disajikan pada Gambar 1.

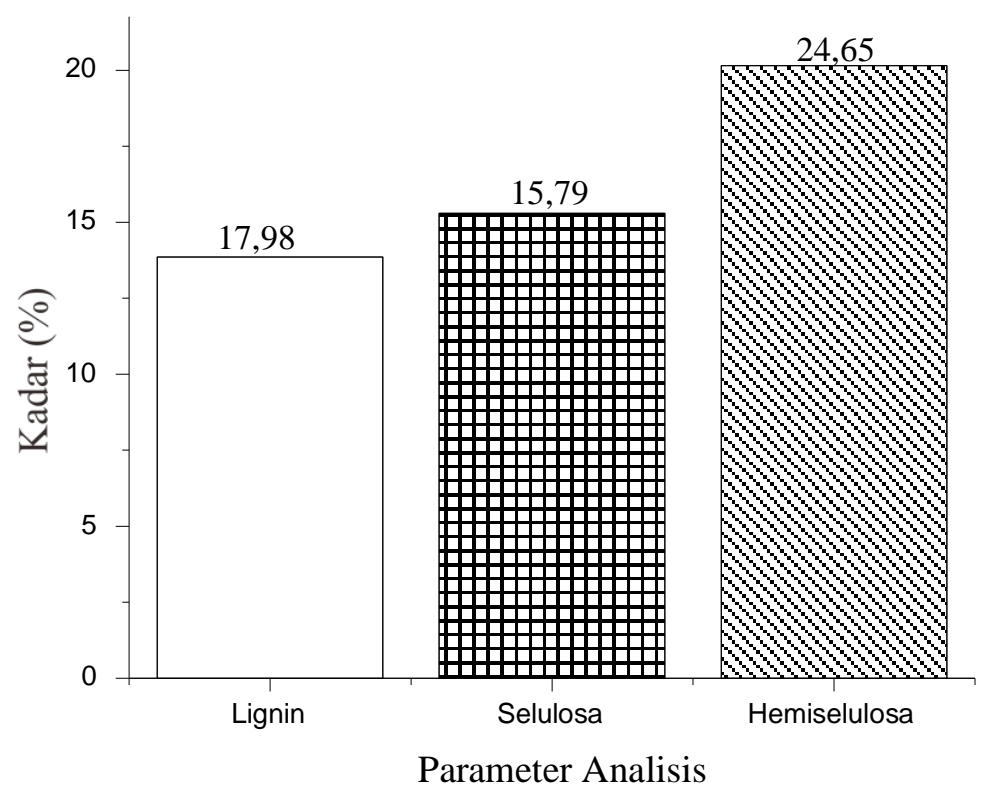

Gambar 1. Kandungan lignin, selulosa dan hemiselulosa pada L. minor

Data awal ini nantinya akan digunakan sebagai data pembanding untuk melihat efektivitas dari proses pretreatment yang dilakukan.

\section{Pretreatment bertingkat}

Pretreatment merupakan proses yang memegang peranan sangat penting dalam pembuatan bioetanol dari biomassa. Hal tersebut disebabkan karena pada tahap ini dilakukan proses degradasi terhadap lignin dan hemiselulosa. Lignin dan hemiselulosa menjadi kendala utama dalam proses pembuatan bioetanol disebabkan struktur lignin dan hemiselulosa yang begitu keras dan kaku sehingga pada tahap fermentasi, yaitu tahap biokonversi gula menjadi bioetanol mejadi tidak maksimal. Pada penelitian ini proses pretreatment dilakukan secara bertingkat yaitu dengan metode fisika (hydrothermal pressure) dan metode kimiawi (pelarut alkali natrium hidroksida).

\section{Hydrothermal pressure pretreatment}

Pretreatment dengan metode hydrothermal pressure dilakukan dengan menggunakan autoklaf pada suhu $121{ }^{\circ} \mathrm{C}$ dengan tekanan 15-20 psi. Sampel L. minor dengan jumlah yang sama ditimbang sebanyak $10 \mathrm{~g}$ dan diberian perlakuan dengan variasi lama pemanasan. Pada proses ini pemanasan dilakukan dengan 5 variasi waktu yang berbeda yaitu 5, 15, 30, 45, dan 60 menit. Hal ini bertujuan untuk menentukan efektivitas waktu pretreatment dengan hydrothermal pressure terhadap laju degradasi lignin dan 
hemiselulosa serta peningkatan kadar selulosa. Berdasarkan penelitian yang di lakukan diperoleh hasil berdasarkan data pada Tabel 1.

Tabel 1. Hasil analisis kadar lignin, selulosa dan hemiselulosa dengan metode hydrothermal pressure preteatment

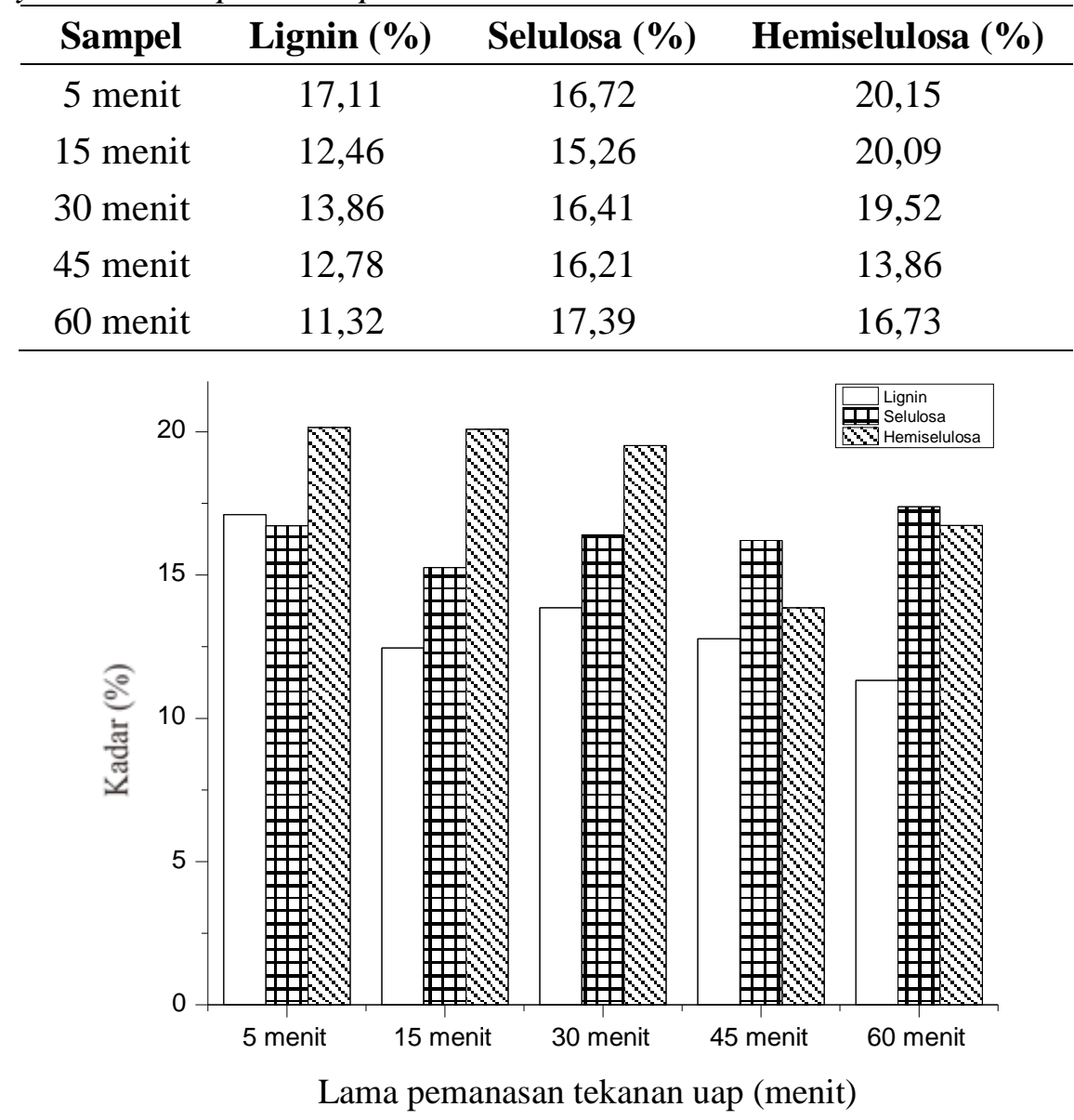

Gambar 2. Pengaruh lama pemanasan hydrothermal pressure terhadap penurunan dan peningkatan kadar liginin, hemiselulosa, selulosa

Berdasarkan data pada Gambar 2 selama 5 menit, 10 menit, 15 menit, 30 menit dan 45 menit berturut-turut menyebabkan degradasi kadar lignin sebesar 4,84\%, 30,70\%, $22,91 \%, 22,91 \%, 28,92 \%$ dan 37,04\%. Hasil penelitian menunjukkan bahwa waktu pretreatment optimum diperoleh pada waktu 60 menit. Hal tersebut terjadi karena pada pemanasan 60 menit kadar lignin dan hemiselulosa mengalami degradasi yang cukup signifikan serta peningkatan kadar selulosa dalam sampel dan penurunan kadar hemiselulosa jika dibandingkan dengan data tahap awal sampel tanpa perlakuan seperti pada Gambar 1. Terlihat bahwa pretreatment dengan metode hydrothermal pressure yang semakin lama cenderung menyebabkan kadar lignin pada sampel L.minor menurun. Penurunan tersebut diindikasikan karena ligin mengalami degrabilitas oleh pengaruh panas tinggi dan tekanan dengan intensitas waktu yang cukup lama, akibatnya stabilitas struktur 
lignin yang kaku dan rigid menjadi menurun. Pada tahap ini efektivitas reduksi kadar lignin yang terkandung dalam L.minor sebesar 37,04\%. Tahap selanjutnya dilakukan analisis terhadap kadar gula total untuk masing-masing perlakuan. Berdasarkan hasil analisis kadar gula total dengan metode Luff Schoorl (AOAC, 2000) diperoleh data seperti pada Gambar 3.

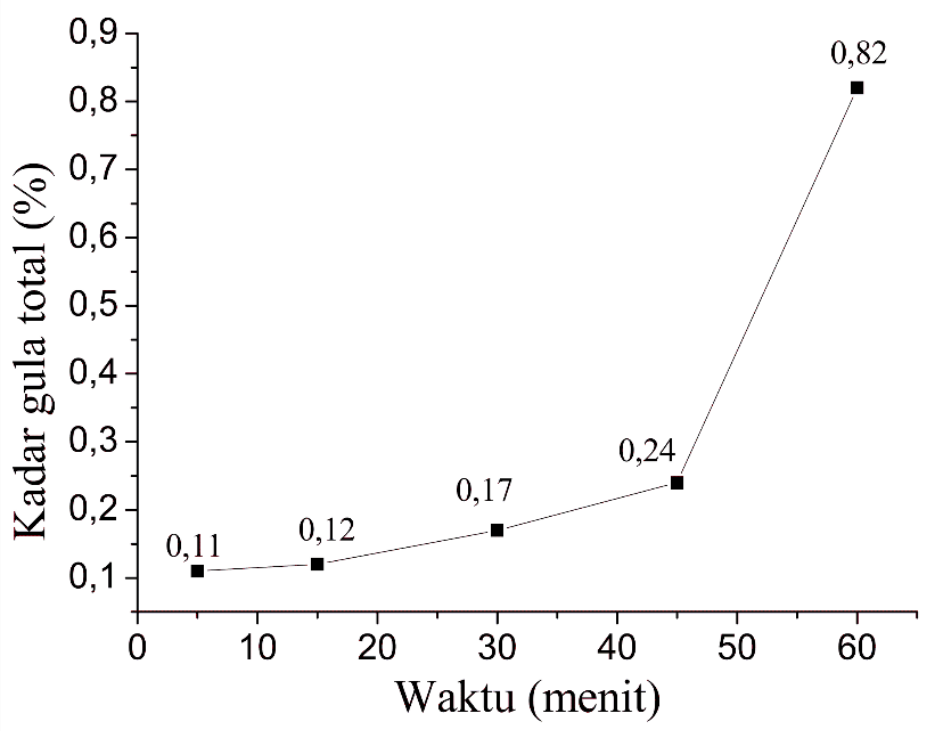

Gambar 3. Kadar gula total sampel hasil pretreatment dengan metode hydrothermal pressure

Hasil analisis kadar gula total menunjukkan bahwa waktu optimum pretreatment dengan metode hydrothermal pressure pada selang waktu 60 menit. Kadar gula total yang diperoleh pada waktu optimum sebesar $0,82 \%$. Pada pretreatment hydrothermal pressure selama 5 menit, 15 menit, 30 menit dan 45 menit diperoleh kadar gula total berturut-turut sebesar $0,11 \%, 0,12 \%, 0,17 \%$, dan 0,24\%. Pretreatment dengan hydrothermal pressure diindikasikan menyebabkan terjadinya pemecahan gula kompleks menjadi gula sederhana. Selulosa dan hemiseluosa yang terkandung dalam biomassa L.minor mengalami pemecahan ikatan glikosidik akibat pemanasan tinggi dengan tekanan sehingga menyebabkan terbentuknya oligomer, dimer maupun monomer dari glukosa. Hal tersebut berpengaruh terhadap meningkatnya kadar gula total pada sampel L.minor dengan perlakuan awal hydrothermal pressure yang lebih lama (Brebu and Vasile, 2010).

\section{Pretreatment dengan Pelarut Alkali}

Pada proses pretreatment dengan pelarut alkali $(\mathrm{NaOH})$ dilakukan dengan variasi konsentrasi $\mathrm{NaOH}$. Penggunaan variasi konsentrasi bertujuan untuk melihat pengaruh konsentrasi terhadap laju degradasi lignin dan hemiselulosa. Perlakuan awal terhadap sampel dilakukan dengan metode hydrothermal pressure selama 60 menit. Hal tersebut 
untuk memudahkan proses degradasi lignin dengan $\mathrm{NaOH}$. Sampel ditimbang sebanyak 10 gram lalu kemudian di larutkan dengan $\mathrm{NaOH}$ dengan perbandingan 1 : 10 lalu diaduk dengan magnetic stirrer selama 1 jam. Variasi konsentrasi $\mathrm{NaOH}$ yang digunakan antara lain 0,$5 ; 1,0 ; 1,5 ; 2,0 ;$ dan $2,5 \mathrm{M}$. Indikasi larutnya lignin pada $\mathrm{NaOH}$ dapat dilihat dari filtrat sampel yang berwarna hitam kecoklatan. Setelah satu jam sampel dicuci dengan akuades hingga netral lalu di keringkan dalam oven pada suhu $80{ }^{\circ} \mathrm{C}$. Selanjutnya, kadar lignin, selulosa dan hemiselulosa dianalisis dengan metode metode Chesson (Datta, 1981). Berdasarkan hasil analisis diperoleh data seperti yang terlihat pada Tabel 2.

Tabel 2. Hasil analisis kadar lignin, selulosa dan hemiselulosa dengan alkaline pretreatment

\begin{tabular}{cccc}
\hline Konsentrasi sampel (M) & Lignin (\%) & Selulosa (\%) & Hemiselulosa (\%) \\
\hline 0,5 & 10,6 & 26,69 & 13,91 \\
1 & 9,22 & 25,66 & 13,58 \\
1,5 & 5,96 & 27,99 & 14,14 \\
2 & 5,36 & 27,23 & 9,05 \\
2,5 & 5,68 & 31,03 & 5,57 \\
\hline
\end{tabular}

Hasil analisis yang diperoleh menunjukkan bahwa efektivitas optimum degradasi lignin yang terkandung dalam sampel L.minor diperoleh pada konsentrasi $\mathrm{NaOH} 2 \mathrm{M}$ dengan nilai reduksi lignin sebesar 52,63\%. Adapun reduksi lignin pada $\mathrm{NaOH} 0,5 \mathrm{M}$ sebesar 6,36\%, reduksi lignin pada konsentrasi $\mathrm{NaOH}$ 1,0 M sebesar 18,57\%, reduksi lignin pada konsentrasi $\mathrm{NaOH}$ 1,5 $\mathrm{M}$ sebesar 47,33\% dan reduksi lignin pada konsentasi $\mathrm{NaOH} 2,5 \mathrm{M}$ sebesar 49,78\%. Efektivitas degradasi lignin dengan $\mathrm{NaOH}$ menunjukkan hasil yang cukup baik hal tersebut terlihat dari nilai efektivitas degradasi lebih dari $50 \%$. Namun, terjadi perbedaan pada konsentrasi 2,0 M dan 2,5 M. Pada tahapan preparasi sampel reduksi ukuran partikel telah dilakukan hingga 60 mesh sehingga efektivitas sampel seharusnya diperoleh pada konsentrasi 2,5 M. Menurut Sun and Cheng (2002) ukuran partikel akan meningkatkan porositas sampel yang mempengaruhi kontak terhadap senyawa delignifikator dan juga sebagai salah satu cara untuk memutuskan rantai polimer menjadi lebih pendek sehingga lignin lebih mudah untuk terpisah. Penggunaan senyawa alkali seperti $\mathrm{NaOH}$ pada proses alkaline pretreatment dapat menyebabkan pecahnya struktur lignin sehingga kadar lignin semakin berkurang. Adanya perbedaan tersebut diindikasikan terjadi karena faktor pengadukan sampel yang kurang homogen sehingga interaksi antara pelarut dengan sampel kurang menjadi maksimal. 


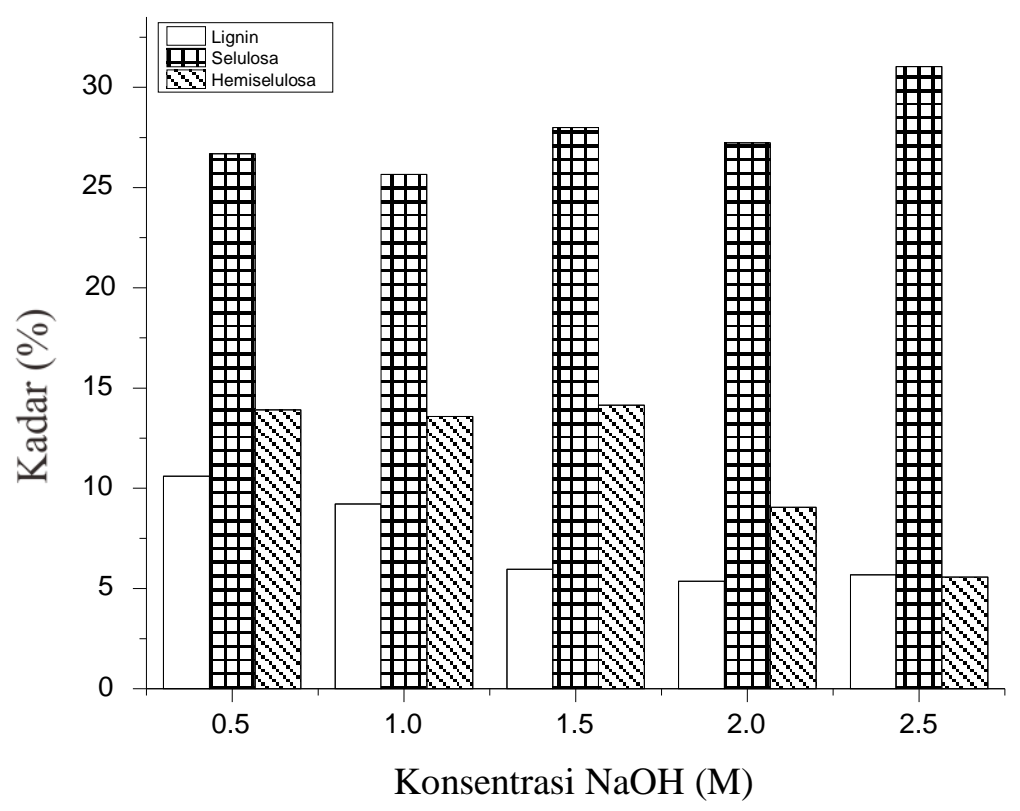

Gambar 4. Data pengaruh konsentrasi $\mathrm{NaOH}$ terhadap penurunan dan peningkatan kadar liginin, hemiselulosa, selulosa

Analisis kadar gula total sampel dilakukan dengan metode Luff Schoorl (AOAC, 2000) seperti ditunjukkan pada Gambar 5.

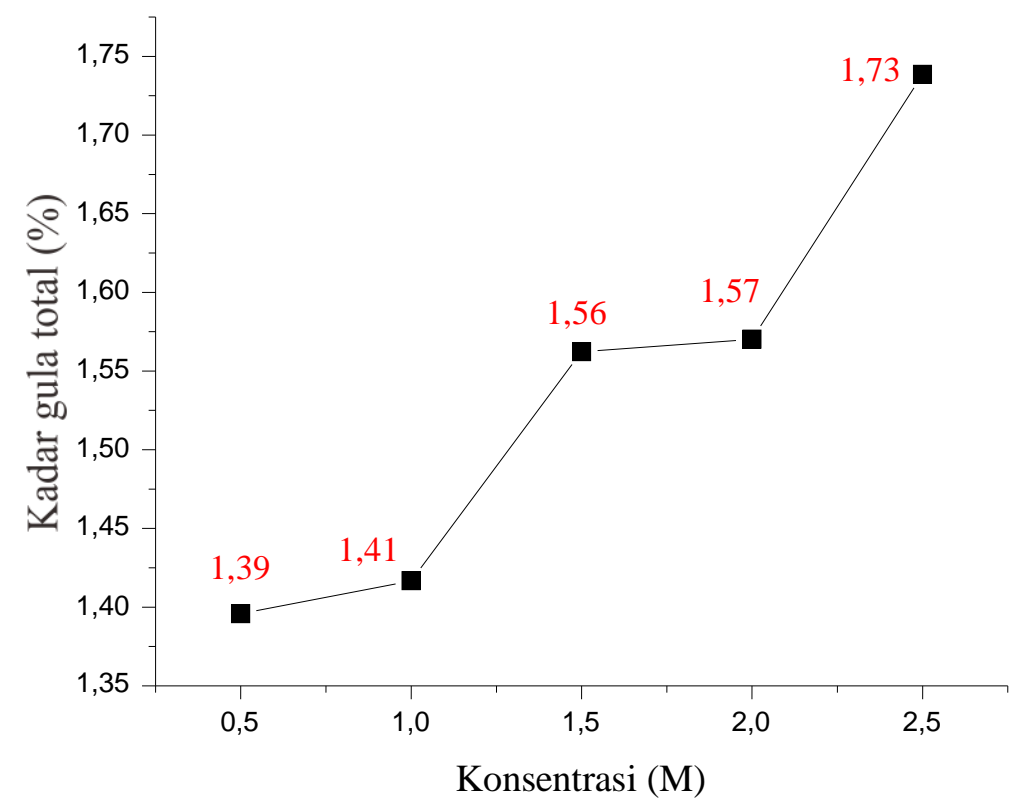

Gambar 5. Kadar gula total sampel hasil alkaline pretreatment

Hasil analisis kadar gula total menunjukkan konsentrasi 2,5 M merupakan konsentrasi optimum dengan nilai kadar gula total sebesar 1,74\%. Adapun nilai kadar gula total konsentrasi alkali dapat dilihat pada Gambar 5. Peningkatan kadar gula total semakin tinggi seiring dengan bertambahnya konsentrasi larutan. Peningkatan konsentrasi $\mathrm{NaOH}$ mengakibatkan terdegradasinya ikatan glikosidik pada rantai polimer selulosa dan 
hemiselulosa. Faktor peningkatan porositas sampel juga memegang peranan penting dalam meningkatkan kadar gula total pada konsentasi tinggi. Hal ini dikarenakan $\mathrm{NaOH}$ dengan konsentrasi tinggi efektif melarutkan lignin, mendegradasi struktur hemiselulosa sehingga meningkatkan kadar gula total pada sampel.

\section{KESIMPULAN}

Perlakuan awal dengan metode hydrothermal pressure memberikan efektivitas penurunan kadar lignin sebesar 37,04\% dengan waktu optimum selama 60 menit. Kandungan kadar lignin sampel L. minor setelah waktu pretreatment selama 60 menit sebesar $11,32 \%$, kadar selulosa 17,39\%, kadar hemiselulosa $16,73 \%$ dan kadar gula total $0,82 \%$. Untuk tahapan pretreatment dengan pelarut alkali $(\mathrm{NaOH})$ memberikan efektivitas penurunan kadar lignin sebesar 70,18\% dengan konsentrasi $\mathrm{NaOH}$ 2,0 M. Kandungan kadar lignin L. minor setelah pretreatment dengan $\mathrm{NaOH}$ 2,0 M sebesar 5,36\%, kadar. Kandungan kadar selulosa, hemiselulosa dan gula total optimum diperoleh pada konsentrasi 2,5 M dengan nilai kadar 31,03; 5,57; dan 1,74\%. Proses pretreatment bertingkat dengan mengkombinasikan metode hydrothermal pressure dan pelarut alkali $(\mathrm{NaOH})$ memberikan hasil yang cukup baik terhadap proses degradasi lignin yang terkandung dalam sampel L. minor sehingga sangat efektif digunakan dalam proses pembuatan bioetanol dengan bahan dasar biomassa.

\section{UCAPAN TERIMA KASIH}

Penelitian ini di biayai penuh oleh Universitas Hasanuddin melalui Hibah Penelitian Dosen Pemula tahun 2017.

\section{DAFTAR PUSTAKA}

AOAC, 2000. Official Methods of Analysis $17^{\text {th }}$ Edn, Official Association of Official Analysis Chemists. Gaithersburg, MD.

Atabani A.E., Silitonga A.S., Anjum, B.I., Mahlia, T.M.I., Masjuki, H.H., dan Mekhilef, S,. 2012. A Comprehensive Review on Biodiesel as an Alternative Energy Resource and Its Characteristics. Renewable and Sustainable Energy Reviews 16 (4), 2070-93.

Ballesteros, I., Negro, M. J., Oliva, J. M., Cabañas, A., Manzanares, P., \& Ballesteros, M. (2006). Ethanol Production From Steam-Explosion Pretreated Wheat Straw. Applied Biochemistry and Biotechnology 129, 496-508.

Brebu, M., dan Vasile, C., 2010. Thermal Degradation of Lignin-a Review. Cellulose Chemistry \& Technology 44 (9), 353-63. 
Datta, R., 1981. Acidogenic Fermentation of Lignocellulose-Acid Yield and Conversion of Components. Biotechnology and Bioengineering 23 (9), 2167-70.

Gu, T., Held, M. A., and Faik, A., 2013. Supercritical $\mathrm{CO}_{2}$ and Ionic Liquids for the Pretreatment of Lignocellulosic Biomass in Bioethanol Production. Environmental Technology 34 (13-14), 1735-49.

Gwaze, F.R.,and Mwale, M., 2015. The Prospect of Duckweed in Pig Nutrition: A Review. Journal of Agricultural Science 7 (11), 189-99.

Ko, J. K., Bak, J. S., Jung, M. W., Lee, H. J., Choi, I. G., Kim, T. H., \& Kim, K. H., 2009. Ethanol Production from Rice Straw Using Optimized Aqueous-Ammonia Soaking Pretreatment and Simultaneous Saccharification and Fermentation Processes. Bioresource Technology 100 (19), 4374-80.

Li, C., Knierim, B., Manisseri, C., Arora, R., Scheller, H.V., Auer, M., Vogel, K.P., Simmons, B.A., and Singh, S., 2010. Comparison of Dilute Acid and Ionic Liquid Pretreatment of Switchgrass: Biomass Recalcitrance, Delignification and Enzymatic Saccharification. Bioresource Technology 101 (13), 4900-4906.

Marrubini, G., Papetti, A., Genorini, E., and Ulrici, A., 2017. Determination of the Sugar Content in Commercial Plant Milks by Near Infrared Spectroscopy and LuffSchoorl Total Glucose Titration. Food Analytical Methods 10 (5), 1556-67.

Parisutham, V., Kim, T.H., and Lee, S.K., 2014. Feasibilities of Consolidated Bioprocessing Microbes: From Pretreatment to Biofuel Production. Bioresource Technology 161, 431-40.

Selig, M.J., Vinzant, T.B., Himmel, M.E., and Decker, S.R., 2009. The Effect of Lignin Removal by Alkaline Peroxide Pretreatment on the Susceptibility of Corn Stover to Purified Cellulolytic and Xylanolytic Enzymes. Applied Biochemistry and Biotechnology 155 (1-3), 397-406.

Sun, Y., and Cheng, J., 2002. Hydrolysis of Lignocellulosic Materials for Ethanol Production : A Review Q. Bioresource Technology 83 (1), 1-11.

Wan, C., and Li, Y., 2012. Fungal Pretreatment of Lignocellulosic Biomass. Biotechnology Advances 30 (6), 1447-57.

Xu, J., Cui, W., Cheng, J.J., and Stomp, A.M., 2011. Production of High-Starch Duckweed and Its Conversion to Bioethanol. Biosystems Engineering 110 (2), 67-72.

Zhao X., Moates G. K., Wellner N., Collins S. R A., Coleman M. J., and Waldron K. W., 2014. Chemical Characterisation and Analysis of the Cell Wall Polysaccharides of Duckweed (Lemna Minor). Carbohydrate Polymers 111, 410-18. 